\title{
An Ethno botanical Study for the Treatment of Cancer and Malaria Used by the People of Quetta City
} Misbah Manzoor ${ }^{1}$, Mufakhirah jan Durrani ${ }^{1}$, Rukhsana Jabeen $^{2}$, Shazia Irfan $^{2}$,
Farkhanda Ayub
, Sidra Bibi

'Lecturer, Department of Botany, Sardar Bahadur Khan Women's University, Quetta.

Email: Alfa_botany@yahoo.com

${ }^{1}$ Chairperson, Biology Department, Allama Iqbal Open Uiversity,Islamabad.

${ }^{2}$ Dean of Natural Sciences, Department of Botany, Sardar Bahadur Khan Women's University, Quetta.

${ }^{2}$ Lecturer, Department of Botany,

Sardar Bahadur Khan Women's University, Quetta.

${ }^{3}$ Student, Department of Botany,

Sardar Bahadur Khan Women's University, Quetta.

${ }^{3}$ Student,

Department of Environmental Sciences, Sardar Bahadur Khan Women's University, Quetta. 


\begin{abstract}
Cancer and Malaria are the common diseases affecting the citizens of both developed and poor countries. An ethno-botanical survey was conducted at Sardar Bahadur Khan Women's university campus, From March to November 2010. Ethno-botanical information was collected from faculty and students on Sardar Bahadur Khan Women's university campus and interviewing local people. This study was mainly focused on indigenous knowledge about the fruits, vegetables and herbs used for the treatment of cancer and malaria. The attempt was endured to collect indigenous knowledge with details of their local names, part used, distributed and recipes of medicinal use etc. In this study, 50 plants were recorded belonging to 32 species. It was observed that plants of the family Cucurbitaceae (4 Species) are most commonly used for the treatment of cancer. And family Lamiaceae (3 species) and family Rutaceae (3species) are most commonly used for the treatment of malaria. The most studied species used for the cancer treatment are Caralluma Tuberculate (Asclepiadaceae), Cucurbita maxima (Cucurbitaceae), Luffa acutangula (Cucurbitaceae), Fragaria vesca (Rosaceae), Spinacea oleracea (Chenopodiaeae). Moreover, the most studied species used for the malaria treatment are Citrus limonia (Rutaceae) Juniperus excelsa (Cupressaceae), and Momordica charantia (Cucurbitaceaea). It is suggested that the use of herbs for cancer and malaria is more secure as compared to synthetic medicines.
\end{abstract}

Key words: Fruits, Vegetables, Herbs, Cancer, Malaria. Socioeconomic documentation.

\title{
1 Introduction
}

Approximately 6000 plant species with medicinal properties are found in Pakistan. Scientific has done a lot of research work on medicinal plant components and usage. Plants, roots, bark, leaves, seeds and flowers have contributed immensely to ruler's health care through the provision of drugs for treatment of ailments. There are different types of fruits, vegetables and herbs which are used for the treatment of different diseases such as malaria and cancer. Ethno botanical information about anti-malarial plants, used in traditional herbal medicine, is essential for the further evolution of the efficacy of plant antimalarial remedies and for isolating and identifying of new anti-malarial drugs. The two main groups of modern antimalarial drug artemisinin and quinine derivatives are known to have their source from herbs. Studies have documented over 1,200 plant species from 160 families used in the treatment of malaria or fever [3].

Malaria is a global disease that is prominent in the tropics and caused by blood parasite, Plasmodium falciparum, plasmodium ovale, and plasmodium malariae, and plasmodium vivax. Malaria has a greater morbidity and mortality than any other infectious diseases of the world [2]. Estimated number of annual malaria 
episodes in Pakistan is 1.5 million. In 2005, falciparum malaria constituted $33 \%$ of reported confirmed malaria cases, $40 \%$ of cases were reported from Balochistan province. Balochistan in its yearly reports showed positivity rate of $P$. vivax $6.6 \%$, and $P$ falciparum $11.2 \%$, in 2004, 2005, and 2006 respectively. Sheikh et al [7] observed slide positivity 34.8\% in Quetta during 1994-1998 [4],[5], [6].

The use of plant-derived drugs for the treatment of malaria has a long and successful tradition. For example, quinine isolated from Cinchona and quinghaosu from Artemisia annиa $L$. Illustrates the potential value of investigating traditionally used anti-malarial plants for developing pharmaceutical anti-malarial drugs (several plant species including Alstonei boonei De Willd (Apocynaceae), Azadirachta indica A. Juss, (Meliaceae), Cryptolepis sanguinolenta (Lindl.) Schttr. (Asclepidaceae), Morinda lucida Benth. (Rubiaceae), Nauclea latifolia Sm. (Rubiaceae) and Ocimum viride Willd. (Lamiaceae) are used in the treatment of malaria [8].

It caused about $13 \%$ of all human deaths in 2007 (7.6 million). Cancers are primarily an environmental disease with $90-95 \%$ of cases due to lifestyle and environmental factors and 5-10\% due to genetics. Plants have long been used in the National Cancer Institute collected about 35,00 plant samples from 20 countries and has screened around 114,000 extracts for anticancer drugs commercially available prior to 1983 in the US and among worldwide approved anticancer drugs between 1983 and 1994, 60\% are of natural origin. It has been reported that among the different dietary components of fruits and vegetables, secondary plant constituents (such as phytotochemicals) play a major role in disease prevention [1].The following foods have the ability to help stave off cancer and some can even help inhibit cancer cell growth or reduce tumor size. Broccoli, cabbage, and cauliflower contains indole-3-carbinol that can reduce the breast cancer .Carrots contain a lot of beta carotene, which may help reduce a wide range of cancers including lung, mouth, throat, stomach, intestine, bladder, prostate and breast. Garlic as well as onions; contain immune-enhancing alliums compounds, which lower risk of stomach and colon cancer. Grapefruits, like oranges and other citrus fruits, contain monoterpenes, believed to help prevent cancer. Nuts contain the antioxidants quercetin and campferol that may suppress the growth of cancers. Oranges and lemons contain Limonene, which stimulates cancer-killing immune cells that may also break down cancer-causing substances. Teas: Green Tea and Black tea contain certain antioxidants known as polyphenols, which appear to prevent cancer cells from dividing. Tomatoes contain lycopene, an antioxidant that are suspected of triggering cancer. The aim of my study was to collect information from the group of students and faculty of the university and interviewed some local people about their current traditional uses of fruits vegetables and herbs for the treatment of malaria and cancer. 


\section{Materials and methods}

\subsection{Data Collection}

The present study focused on herbs, fruits, and vegetables used to treat cancer and malaria. About 60 students and faculty from different departments were personally interviewed and asked questions regarding traditional uses of plants and their local name, their recipes, parts, uses and record other medicinal uses. The ethno botanical information and traditional uses of fruits vegetables and herbs for said purpose the data were collected systematically on malaria and cancer treatment questionnaires, semi- structured interviews and discussions. Collected data were also crossed checked in different areas from local inhabitants or identified with the help of floristic materials. (Nasir and Ali, 1970-1989); Ali and Nasir 1990-1991; Ali and Qaiser, 1993, 2001.

\subsection{Collection of Plants}

Plants were collected from different sites of Quetta city. The plants were collected from the hills, plains, and healers and herbalists. The plants were identified by local peoples of the area and then pressed them in presser and were taken to laboratory for identification. The plants were identified by their vernacular name. The botanical names of medicinal plants are listed in alphabetical order and listed their families and vernacular name. Hakims and parsers were also interviewed regarding the use of medicinal plants.

\section{RESULTS AND DISCUSSIONS}

Data obtained from the present study is compiled in Tables 1.1, 1.2, 1.3, and 1.4 and the plant species are arranged in alphabetic order. From the ancient times to date, people treated themselves with fruits, vegetables and traditional herbal medicines. The 50 species related to 32 families of fruits, the students and faculty of Sardar Bahadur Khan Women's University campus and local people for the treatment of malaria and cancer diseases use vegetables and herbs. For each plant species botanical name, local name, family, part used, recipes are recorded.

One purpose of this ethno botanical study was to record the indigenous knowledge about plants. It was felt worthwhile to record the native uses of fruits, vegetables and herbs for the treatment of cancer and malaria by the students and faculty of Sardar Bahadur Khan Women's university campus. The local names, part used and methods of preparation were recorded. The present studies in Sardar Bahadur Khan Women University revealed that the older inhabitants have more knowledge and information about the use of fruits, vegetables and herbs for the treatment of cancer and malaria in comparison to younger generation and same in case of illiterate to literate people. Most of the remedies have been taken orally in the 
form of decoction or extraction or paste. Various parts of the plants were utilized in the preparation of anti-malarial and anti-cancer herbal remedies The part utilized showed that most of the anti-malarial and anti-cancer drugs are obtained from fruits, roots, seeds, extract and sometimes the whole plant is uprooted and used in the preparation of the drugs.

Maximum number of species used for the treatment of cancer disease belonging to families like Cucurbitaceae (4species), Rosaceae (3species), Cruciferous (2species), Liliaceae (2species), Agaricaceae (1specie), Anacardiaceae (1specie), Apocynaceae (1specie), Asclepiadaceae (1specie), Caricaceae (1specie), Chenopodiaceae (1specie), Moraceae (1specie), Musaceae (1specie), Myrtaceae (1specie), Palmaceae (1specie), Sapotaceae (1specie), Solanaceae (1specie), Theaccae (1specie), Umbelleferas (1specie).

Maximum number of species used for the treatment of malaria disease belonging to Families like Asteraceae (3species), Lamiaceae (3species), Rutaceae (3species), Cucurbitaceae (2species), Rubiaceae (2species), Apiaceae (1specie), Compositeae (1specie), Convolvulaceae (1specie), Cupressaceae (1specie), Ephedraceae (1specie), Juglandaceae (1specie), Malvaceae (1specie), Palmaceae (1 specie), Poaceae (1specie), Punicacceae (1specie), Rosaceae (1specie), Vitaceae (1specie).

It was observed during the survey that plants of the family cucurbitaceae 4 species were most commonly used for the treatment of cancer. Family Asteraceae and Lamiaceae plants were most commonly used for the treatment of malaria. The most utilized anticancer plant species were: Caralluma Tuberculate (Asclepiadaceae), Cucurbita maxima (Cucurbitaceae), Luffa acutangula (Cucurbitaceae), Fragaria vesca (Rosaceae), and Spinacea oleracea (Chenopodiaeae) (Table 1.1) and most utilized antimalarial plant species were: Citrus limonia (Rutaceae), Juniperus excelsa (Cupressaceae), and Momordica charantia (Cucurbitaceaea) (Table 1.3). Different plant parts used to cure cancer and malaria. Among these fruits were highly utilized followed by whole plant, leaves, roots, seeds,juice (Table 1.2 and 1.4).

Table 1.1. Showing Fruits, vegetables and herbs for the treatment of Cancer

\begin{tabular}{|l|l|l|l|}
\hline S.NO & BOTANICALNAME & LOCAL NAME & FAMILY \\
\hline 1. & Achras sapota & Chiku(Sapodilla) & Sapotaceae \\
\hline 2. & Agaricus campestris & Kumbi (Mushroom) & Agaricaceae \\
\hline 3. & Allium cepa & Piaz (Onion) & Liliaceae \\
\hline 4. & Allium sativum & Thoom (Garlic) & Liliaceae \\
\hline 5. & Brassica cabitata & Bandgobi (Cabbage) & Cruciferae \\
\hline
\end{tabular}




\begin{tabular}{|c|c|c|c|}
\hline 6. & Brassica oleracea & Kale (Borecole) & Cruciferae \\
\hline 7. & Carica papaya & Papita (Pappya) & Caricaceae \\
\hline 8. & Camellia Sinensis & Tea & Theaccae \\
\hline 9. & Caralluma Tuberculate & Marmootk/Marmoot & Asclepiadaceae \\
\hline 10. & Citrullus vulgaris & $\begin{array}{l}\text { Hadwana (Water } \\
\text { melon) }\end{array}$ & Cucurbitaceae \\
\hline 11. & Cucurbita maxima & Walaiti kadoo & Cucurbitaceae \\
\hline 12. & Cucurbita pepo & Gia kadoo & Cucurbitaceae \\
\hline 13. & Daucus carota & Gajar (Carrot) & Umbelleferas \\
\hline 14. & Eugenia jambolana & Jaman (Balac palm) & Myrtaceae \\
\hline 15. & Fiscus Carica & Anjeer (Fig) & Moraceae \\
\hline 16. & Fragaria vesca & Strawberry & Rosaceae \\
\hline 17. & Luffa acutangula & Kali tori (Loofah) & Cucurbitaceae \\
\hline 18. & $\begin{array}{l}\text { Lycopersicum } \\
\text { esculentun }\end{array}$ & Tamatar (Tomato) & Solanaceae \\
\hline 19. & Mangifera indica & Am (Mango) & Anacardiaceae \\
\hline 20. & Musa papadisiaca & Kela (Banana) & Musaceae \\
\hline 21. & Phoenix dactylifera & Khajoor (Date/palm) & Palmaceae \\
\hline 22. & Prunus domestica & Khurmani (Apricot) & Rosaceae \\
\hline 23. & Prunus persica & Aru (Peach) & Rosaceae \\
\hline 24. & Rhazya strictea & Aizwarg & Apocynaceae \\
\hline 25. & Spinacea oleracea & Palak(Spinach) & Chenopodiaeae \\
\hline
\end{tabular}

Table 1.2. Showing part used and traditional recipes of Fruits, vegetables and herbs for the treatment of Cancer

\begin{tabular}{|l|l|l|c|}
\hline S.No & $\begin{array}{l}\text { BOTNICAL } \\
\text { NAME }\end{array}$ & $\begin{array}{l}\text { PART } \\
\text { USED }\end{array}$ & $\begin{array}{c}\text { METHOD OF PERPARATION OF } \\
\text { DIFFERENT RECEPIES }\end{array}$ \\
\hline 1. & Achras sapota & $\begin{array}{l}\text { Fruits } \\
\text { Juice }\end{array}$ & Fresh fruits are cut in to slices and given \\
\hline
\end{tabular}




\begin{tabular}{|c|c|c|c|}
\hline & & & $\begin{array}{l}\text { to the patient daily for a month or used as } \\
\text { a juice. }\end{array}$ \\
\hline 2. & $\begin{array}{l}\text { Agaricus } \\
\text { campestris }\end{array}$ & Whole part & $\begin{array}{l}\text { The whole fresh part is boiled in water } \\
\text { and used as a food twice a day for a } \\
\text { week. }\end{array}$ \\
\hline 3. & Allium cepa & Root & $\begin{array}{l}\text { Prepare onion content and taken along } \\
\text { with food. }\end{array}$ \\
\hline 4. & $\begin{array}{l}\text { Allium } \\
\text { sativum }\end{array}$ & Whole plant & $\begin{array}{l}\text { Make a paste of whole plant then take } \\
\text { one tea spoon along with food twice a } \\
\text { day for a month. }\end{array}$ \\
\hline 5. & $\begin{array}{l}\text { Brassica } \\
\text { cabitata }\end{array}$ & Flower & $\begin{array}{l}\text { Fresh flowers are cooked as vegetable } \\
\text { and given to the patient for two to three } \\
\text { weeks. }\end{array}$ \\
\hline 6. & $\begin{array}{l}\text { Brassica } \\
\text { oleracea }\end{array}$ & Flower & $\begin{array}{l}\text { Fresh flowers are cooked as vegetable } \\
\text { and given to the patient twice a day for } \\
\text { long period of time. }\end{array}$ \\
\hline 7. & Carica papaya & Fruits & $\begin{array}{l}\text { Fresh fruits are cut into pieces and given } \\
\text { to the patient twice a day for long period } \\
\text { of time or used as a juice. }\end{array}$ \\
\hline 8. & $\begin{array}{l}\text { Camellia } \\
\text { Sinensis }\end{array}$ & Leaves & $\begin{array}{l}\text { Leaves are boiled with water along with } \\
\text { sugar and used as a tea and used two } \\
\text { cups twice a day for three months. }\end{array}$ \\
\hline 9. & $\begin{array}{l}\text { Caralluma } \\
\text { Tuberculate }\end{array}$ & Whole plant & $\begin{array}{l}\text { Whole plant is dried and powder is } \\
\text { applied on wounds. }\end{array}$ \\
\hline 10. & $\begin{array}{l}\text { Citrullus } \\
\text { vulgaris }\end{array}$ & Fruits & $\begin{array}{l}\text { Fresh fruits are cut in to slices and given } \\
\text { to the patient daily at night for long } \\
\text { period or used as a juice. }\end{array}$ \\
\hline 11. & Cucurbita & Fruits & Fresh fruit is cooked as vegetable and \\
\hline
\end{tabular}




\begin{tabular}{|c|c|c|c|}
\hline & maxima & & used weekly. \\
\hline 12. & $\begin{array}{l}\text { Cucurbita } \\
\text { pepo }\end{array}$ & Fruits & $\begin{array}{l}\text { Fresh fruit is cooked as vegetable and } \\
\text { given to the patient weekly for long } \\
\text { period of time. }\end{array}$ \\
\hline 13. & Daucus carota & $\begin{array}{l}\text { Root } \\
\text { Fruits } \\
\text { Juice }\end{array}$ & $\begin{array}{l}\text { Fresh fruits and root are crushed. One } \\
\text { cup of the juice is given to the patient } \\
\text { daily for a month. Or roots are cut in to } \\
\text { slices and taken daily. }\end{array}$ \\
\hline 14. & $\begin{array}{l}\text { Eugenia } \\
\text { jambolana }\end{array}$ & Fruits & $\begin{array}{l}\text { Fresh fruits are cut in to slices and given } \\
\text { to the patient thrice a day for long period } \\
\text { of time. }\end{array}$ \\
\hline 15. & Fiscus Carica & Fruits & $\begin{array}{l}\text { Fresh fruits are eaten daily in large } \\
\text { quantity }\end{array}$ \\
\hline 16 & $\begin{array}{l}\text { Fragaria } \\
\text { vesca }\end{array}$ & Fruits & $\begin{array}{l}\text { Fresh or dried plant materials are first } \\
\text { boil in water. Then two cups of this } \\
\text { decoction taken orally at night for one } \\
\text { week. }\end{array}$ \\
\hline 17. & $\begin{array}{l}\text { Luffa } \\
\text { acutangula }\end{array}$ & Fruits & $\begin{array}{l}\text { Made the soap of fruit and used twice `a } \\
\text { day for a month. }\end{array}$ \\
\hline 18. & $\begin{array}{l}\text { Lycopersicum } \\
\text { esculentum }\end{array}$ & Fruits & $\begin{array}{l}\text { Fresh fruits are cooked as vegetable and } \\
\text { given twice a day for long period. }\end{array}$ \\
\hline 19 & $\begin{array}{l}\text { Mangifera } \\
\text { indica }\end{array}$ & $\begin{array}{l}\text { Fruits } \\
\text { Juice }\end{array}$ & $\begin{array}{l}\text { Taken mango juice daily, which inhibits } \\
\text { the growth cycle of cancer. or used as a } \\
\text { fruit daily for long period of time. }\end{array}$ \\
\hline 20. & $\begin{array}{l}\text { Musa } \\
\text { papadisiaca }\end{array}$ & $\begin{array}{l}\text { Fruits } \\
\text { Juice }\end{array}$ & $\begin{array}{l}\text { Fresh fruit is given to the patient daily for } \\
\text { a month or used as a juice. }\end{array}$ \\
\hline 21. & $\begin{array}{l}\text { Phoenix } \\
\text { dactylifera }\end{array}$ & Fruit & $\begin{array}{l}\text { Phonix dactylifora }+ \text { Milk }+ \text { Mil mixed } \\
\text { together and take early in the morning }\end{array}$ \\
\hline
\end{tabular}




\begin{tabular}{|l|l|l|l|}
\hline & & & $\begin{array}{l}\text { daily before breakfast for two months or } \\
\text { more. }\end{array}$ \\
\hline 22 & $\begin{array}{l}\text { Prunus } \\
\text { domestica }\end{array}$ & Fruit & $\begin{array}{l}\text { Fresh fruits are cut into slices and given } \\
\text { to the patient weekly or used the extract } \\
\text { of fruit daily, }\end{array}$ \\
\hline 23. & $\begin{array}{l}\text { Prunus } \\
\text { persica }\end{array}$ & Fruit & $\begin{array}{l}\text { Fresh fruits are crushed and mixed with } \\
\text { water .then one cup of the extract is } \\
\text { given to the patient twice a day for two } \\
\text { weeks. }\end{array}$ \\
\hline 24 & $\begin{array}{l}\text { Rhazya stricta } \\
\text { oleracea }\end{array}$ & Leaves & $\begin{array}{l}\text { The leaves are soaked in water and with } \\
\text { the decoction washed the cancer wounds. }\end{array}$ \\
\hline 25. & $\begin{array}{l}\text { Spinacea } \\
\text { Leaves }\end{array}$ & $\begin{array}{l}\text { Fresh leaves are cooked as a vegetable } \\
\text { along with garlic and taken weekly for } \\
\text { long period, mostly used for lung and } \\
\text { breast cancer. }\end{array}$ \\
\hline
\end{tabular}

Table 1. 3. Showing Fruits, vegetables and herbs for the treatment of Malaria

\begin{tabular}{|l|l|l|l|}
\hline S.NO & BOTANICAL NAME & LOCAL NAME & FAMILY \\
\hline 1. & Abutilon glaucum & Gulgethar & Malvaceae \\
\hline 2. & Achillea wilhelmii & Boh-E-Madran & Asteraceae \\
\hline 3. & Artemisia scoparia & Red Jir & Asteraceae \\
\hline 4. & Citrus limonia & Lemon & Rutaceae \\
\hline 5. & Coffe Arabica & Coffee & Rubiaceae \\
\hline 6. & Citrus aurantium & Orange & Rutaceae \\
\hline 7. & Citrum medica & Mitha & Rutaceae \\
\hline 8. & Ephedra intermedia & Naromb & Ephedraceae \\
\hline 9. & Ipomoea batatas & Sakar Kandi & Convolvulaceae \\
\hline 10. & Jubertia aucheria & Thusso & Rubiaceae \\
\hline
\end{tabular}




\begin{tabular}{|l|l|l|l|}
\hline 11. & Juglans regia & Akhrot & Juglandaceae \\
\hline 12. & Juniperus excelsa & Apurs & Cupressaceae \\
\hline 13. & Lactuca sativa & Salad & Compositeae \\
\hline 14. & Luffa aegyptiaca & Ghia Tori & Cucurbitaceae \\
\hline 15. & Microcehala lamellate & Pehunpulli & Asteraceae \\
\hline 16. & Momordica charantia & Karela & Cucurbitaceaea \\
\hline 17. & Nepeta praeteruisa & Simsok & Lamiaceae \\
\hline 18. & Punica granatum & Anar & Punicaccea \\
\hline 19. & Prunus Cerasus & Cherry & Rosaceae \\
\hline 20. & $\begin{array}{l}\text { Psammogeton } \\
\text { biternatum }\end{array}$ & Izbotk & Apiaceae \\
\hline 21. & Phoenix dactylifera & Khajoor & Palmaceae \\
\hline 22. & Saccharum begalense & Kashum & Poaceae \\
\hline 23 & Salvia bucharica & Gul-E-Kakar & Lamiaceae \\
\hline 24. & Thymus linearisisbenth & Tormori & Lamiaceae \\
\hline 25. & Vitis vinifera & Angur & Vitacea \\
\hline
\end{tabular}

Table 1. 4. Showing part used and traditional recipes of Fruits, vegetables and herbs for the treatment of malaria.

\begin{tabular}{|l|l|l|l|}
\hline No. & $\begin{array}{l}\text { BOTANICAL } \\
\text { NAMES }\end{array}$ & $\begin{array}{l}\text { PART } \\
\text { USED }\end{array}$ & \multicolumn{1}{c|}{ METHODS OF PREPARITION } \\
\hline 1. & $\begin{array}{l}\text { Abutilon } \\
\text { glaucum }\end{array}$ & $\begin{array}{l}\text { Whole } \\
\text { plant }\end{array}$ & $\begin{array}{l}\text { Abutilon glaucum + salvia cabula (Matetav) boiled } \\
\text { in Water and used early in the morning befre } \\
\text { breakfast For twelve days. }\end{array}$ \\
\hline 2. & $\begin{array}{l}\text { Achillea } \\
\text { wilhelmii }\end{array}$ & $\begin{array}{l}\text { Whole } \\
\text { plant }\end{array}$ & $\begin{array}{l}\text { The whole plant is soaked in water and decoction is } \\
\text { Used early in the morning for a month. }\end{array}$ \\
\hline 3. & $\begin{array}{l}\text { Artemisia } \\
\text { scoparia }\end{array}$ & $\begin{array}{l}\text { Whole } \\
\text { plant }\end{array}$ & $\begin{array}{l}\text { The whole plant is boiled in water and one cup of } \\
\text { decoction is taken daily for five days. }\end{array}$ \\
\hline 4. & Citrus limonia & $\begin{array}{l}\text { Fruits } \\
\text { Juice }\end{array}$ & $\begin{array}{l}\text { Citrus limonia+black pepper+heat for one minute } \\
\text { and takes twice a day for two to three months or }\end{array}$ \\
\hline
\end{tabular}




\begin{tabular}{|c|c|c|c|}
\hline & & & $\begin{array}{l}\text { Green tea citrus limonia juice }+ \text { taken daily at } \\
\text { afternoon time for a month. }\end{array}$ \\
\hline 5. & Coffea Arabica & $\begin{array}{c}\text { Dried } \\
\text { Leaves }\end{array}$ & $\begin{array}{l}\text { Dried leaves are boiled along with water and suger } \\
\text { two cups of decoction is taken daily along with } \\
\text { lemon juice for forty days. }\end{array}$ \\
\hline 6. & $\begin{array}{l}\text { Citrus } \\
\text { aurantium }\end{array}$ & Fruits & $\begin{array}{l}\text { Used as a fruit or or extract the juice of fruit and } \\
\text { taken daily for a week. }\end{array}$ \\
\hline 7. & Citrum medica & Fruits & $\begin{array}{l}\text { Used as a fruit daily,or make the juice of fruit } \\
\text { mixed with lemon and taken daily for a month. }\end{array}$ \\
\hline 8. & $\begin{array}{l}\text { Ephedra } \\
\text { intermedia }\end{array}$ & $\begin{array}{l}\text { Whole } \\
\text { plant }\end{array}$ & $\begin{array}{l}\text { The whole plant is boiled in water and one cup of } \\
\text { decoction is used daily for two months . }\end{array}$ \\
\hline 9. & $\begin{array}{l}\text { Ipomoea } \\
\text { batatas }\end{array}$ & Leaves & $\begin{array}{l}\text { The leaves are boiled in water and decoction is } \\
\text { used For a month at night. }\end{array}$ \\
\hline 10. & $\begin{array}{l}\text { Jubertia } \\
\text { aucheri }\end{array}$ & $\begin{array}{l}\text { Whole } \\
\text { plant }\end{array}$ & $\begin{array}{l}\text { Dry powder of leaves and flower are mixed in the } \\
\text { milk and used daily after meal. }\end{array}$ \\
\hline 11. & Juglans regia & $\begin{array}{l}\text { Dry } \\
\text { seeds }\end{array}$ & $\begin{array}{l}\text { Take the dry seeds and mixed wih milk and taken } \\
\text { Thrice a day for a month. }\end{array}$ \\
\hline 12. & $\begin{array}{l}\text { Juniperus } \\
\text { excela }\end{array}$ & $\begin{array}{l}\text { Seed } \\
\text { Leaves }\end{array}$ & $\begin{array}{l}\text { Seeds are boiled in water and decoction is applied } \\
\text { on body at night weekly.or seeds are mixed with } \\
\text { Microcephala sp and Teucrium stocksianum and } \\
\text { these all are boiled in water and decoction is used } \\
\text { daily for five to ten days. }\end{array}$ \\
\hline 13. & Lactuca sativa & $\begin{array}{l}\text { Dried } \\
\text { leaves }\end{array}$ & $\begin{array}{l}\text { Leaves are dried and made the powdered and } \\
\text { decoction is used daily with one cup of water for } \\
\text { seven days. }\end{array}$ \\
\hline 14. & $\begin{array}{l}\text { Luffa } \\
\text { aegyptiaca }\end{array}$ & Fruits & $\begin{array}{l}\text { Made the soap of fresh fruit along with garlic } \\
\text { andeaten during the meals for twenty days or less. }\end{array}$ \\
\hline 15. & $\begin{array}{l}\text { Microcephala } \\
\text { lamellate }\end{array}$ & $\begin{array}{l}\text { Whole } \\
\text { plant } \\
\text { Leaves }\end{array}$ & $\begin{array}{l}\text { Microcephala lamellate+Teucrium stocksianum } \\
\text { (kalpora) boiled in water and one cup decoction is } \\
\text { used morning and one cup in evening. }\end{array}$ \\
\hline 16. & Momordica & Fruits & Fruit juice mixed with water and drunk after meals \\
\hline
\end{tabular}




\begin{tabular}{|c|c|c|c|}
\hline & charantia & Juice & weekly. \\
\hline 17. & $\begin{array}{l}\text { Nepeta } \\
\text { praeteruisa }\end{array}$ & Leaves & $\begin{array}{l}\text { Tea is made from the leaves and eaten early in the } \\
\text { morning before meal for twenty five days. }\end{array}$ \\
\hline 18. & $\begin{array}{l}\text { Punica } \\
\text { granatum }\end{array}$ & $\begin{array}{l}\text { Fruits } \\
\text { Juice }\end{array}$ & $\begin{array}{l}\text { Fresh fruits are crushed and one cup of the juice is } \\
\text { given to the patient twice a day after the meales. }\end{array}$ \\
\hline 19. & $\begin{array}{l}\text { Prunus } \\
\text { Cerasus }\end{array}$ & Fruits & $\begin{array}{l}\text { Used as a fruit daily in large quantity.or used as a } \\
\text { Juice daily for long period of time. }\end{array}$ \\
\hline 20. & $\begin{array}{l}\text { Psammogeton } \\
\text { biternatum }\end{array}$ & $\begin{array}{l}\text { Whole } \\
\text { plant }\end{array}$ & $\begin{array}{l}\text { The whole plant is grinded to form powder,which } \\
\text { is taken with water twice a day for twenty days. }\end{array}$ \\
\hline 21. & $\begin{array}{l}\text { Phoenix } \\
\text { dactylifera }\end{array}$ & Fruits & $\begin{array}{l}\text { Made the paste of fruit mixed with milk and eaten } \\
\text { daily Early in the morning before breakfast. }\end{array}$ \\
\hline 22. & $\begin{array}{l}\text { Saccharum } \\
\text { begalense }\end{array}$ & Seeds & $\begin{array}{l}\text { Seeds of saccharum begalense+misry grinded and } \\
\text { to make powder and used with tea at night for three } \\
\text { days. }\end{array}$ \\
\hline 23. & Salvia cabulica & $\begin{array}{l}\text { Whole } \\
\text { plant } \\
\text { Leaves }\end{array}$ & $\begin{array}{l}\text { The leaves are soaked in water and the decoction is } \\
\text { Used early in the morning for twelve days. }\end{array}$ \\
\hline 24. & $\begin{array}{l}\text { Salvia } \\
\text { bucharica }\end{array}$ & $\begin{array}{l}\text { Flowers } \\
\text { Leaves }\end{array}$ & $\begin{array}{l}\text { The whole plant is soaked in water and decoction is } \\
\text { used for fifteen days after breakfast. }\end{array}$ \\
\hline 25. & Vitis vinifera & $\begin{array}{l}\text { Fruit } \\
\text { Juice }\end{array}$ & $\begin{array}{l}\text { Juice of fruit is extracted and mixed with milk and } \\
\text { used daily for long period of time. Or used as a } \\
\text { fruit daily. }\end{array}$ \\
\hline
\end{tabular}

\section{Conclusion}

In the present study, 50 medicinal plant species of 32 families used to treat cancer and malaria were reported and documented .The majority of the reported species are wild and rare. Therefore, it is important to conserve such vital resources to optimize their use in the primary health care system. The most dominant ant malarial plant bearing families were Rutaceae (3species), and Lamiaceae (3species). Moreover, the most dominant anticancer plant bearing family was Cucurbitaceae (4species). Now days, conservation of traditional knowledge is very rare due to a lot of factors related to modernization of the region and lack of interest in traditional healers, in transferring to the next generation. If the indigenous knowledge is transferred evenly from older to younger generation, it will help to discover more uses of medicinal plants. The results are equally 
applicable to define the effects of using fruits, vegetables and herbs without any scientifically based approach for its sustainable use and it is intended to facilitate the rapid use of results and the active participation of all partners. It is expected that my work will play a vital role for the students who want to carry out ethnic botany surveys in any other part or area of Balochistan.

\section{ACKNOWLEDGEMENT}

First, I am grateful to Almighty Allah, whose blessings have always given me the strength to complete this task. It is a great honor and privilege for me to record this deep sense of gratitude to my honorable chairperson Dr. Rukhsana their continued guidance and encouragement. My special thanks are for my family especially my mother whose prayers, love and care is the continuous source of encouragement for me.

\section{References}

[1] G. M .Cragg, D. J .Newman, K. M.Snader.1997. Natural products in drug discovery and development. J Nat Pro. 60:52-60.

[2] J. D. Symth . 1994. Animal Parasitology.Cambridge University Pres.

[3] M. Wilcox, G.Burford and G.Bodeker . 2004. An overview of ethno botanical studies on plants used for the treatment of malaria. CRC Press, LLC, 0-415-30112-2.

[4] M.I. Yasinzai ,J.K.Kakarsulemankhel, . 2003. Incidence of malaria infection in rural areas of District Quetta, Pakistan. On Line J .Med .Sci. 3:766-72.

[5] M.I. Yasinzai , J.K.Kakarsulemankhel . 2004. A study of prevalence of malaria infection in urban areas of district Quetta, Pakistan. Pak J Zool. 36: 75-9.

[6] M.I. Yasinzai , J.K.Kakarsulemankhel. 2007. Incidence of malaria infection in central areas of Balochistan. Rawal Med J. 32: 176-8.

[7] A.S.Sheikh, A.A.Sheikh , N.A.Sheikh , S.M.Paracha . 2005. Endemicity of malaria in Quetta. Pak J Med Res. 44:41-5.

[8] K.Srisilam and C.Veersham. 2003. Antimalarial of plants origin. 7:17:47. 